\title{
The THESIS Project
}

\section{Monica Brinzei*}

Keywords: Sentences Commentaries, Intellectual History of Medieval Universities, Paleography, Medieval Manuscripts, Medieval Academic Practices

In 2012 the project THESIS (Theology, Education, Scholastic Institution and Scholarsnetwork: dialogues between the University of Paris and the new Universities from Central and Eastern Europe during the Late Middle Ages) was awarded the ERC starting grant no. 313339 for the period 2012-2018, ${ }^{1}$ having as the host institution the Institut de Recherche et d'Histoire des Textes of the Centre National de la Recherche Scientifique in Paris.

For many centuries, the tradition of lecturing on the Sentences of Peter Lombard was an essential part of mainstream intellectual life, forming the educational cornerstone of medieval faculties of theology, until this work was dethroned in the sixteenth century in favour of the Summa Theologiae of Thomas Aquinas. Of the three postgraduate subjects at the medieval universities, law (canon and civil), medicine and theology, theology was unquestionably the queen. Upon completing their studies in the liberal arts and philosophy, the greatest intellects of the era - Aquinas, Bonaventure, Ockham and so forth - continued their training in theology, culminating in their lectures on the Sentences. These lectures both required and provided an opportunity to display all the knowledge and skills gained in their decades of schooling in logic, ethics, metaphysics and even natural philosophy. A medieval set of questions on the Sentences is thus the unique equivalent of our modern $\mathrm{PhD}$ thesis.

Although the tradition of questions on the Sentences was a global phenomenon in the history of ideas in the Middle Ages, little research has been carried out on late medieval Sentences questions. Yet the corpus of these texts reveals the significant doctrinal innovations of the time, giving us access to the long-term developments in and achievements of late scholastic thought. The systematic theology of the universities of this era forms a bridge between the better-known noetics of the period before the Black Death and later movements, such as Renaissance Humanism, the Reformation and the Scientific Revolution. Erasmus, Luther and Copernicus were, after all, products of the universities. A better understanding of the leading genre of theological discourse helps reveal the impact of theological reflection on the emergence of these new intellectual trends. The study of these texts is also crucial for a greater awareness that the main aim of the university as the medieval institution par excellence was to produce a system of knowledge based mainly on a doctrinal dialogue, attempting to harmonize philosophy and theology by incorporating into the theological discussion epistemological, ethical, logical and scientific notions from very eclectic sources in the Greek, Arabic, Hebrew and Latin traditions, such as Aristotle, the Bible, Augustine, Averroes and Avicenna.

\footnotetext{
* Correspondence details: Monica Brinzei, Directeur de Recherche (DR2), IRHT, CNRS, Paris - Section Latine, 40 av. d'Iena, Paris, 75116, France. Email: mbrinzei@gmail.com.

1 The project had an extension of 10 months due to the amount of new information discovered during the research.
} 
At the end of the fourteenth century - in 1391, to be exact - Jean Gerson, chancellor of the University of Paris, wrote a brief question entitled Pro unione Ecclesiae wherein he showed himself to be very confident concerning the place of the University of Paris within the European intellectual landscape. For this reason, he remarked that "In no other college are there doctors as famous as those who are in the University of Paris, especially in theology «. ${ }^{2}$ Gerson was doubtless unaware that to the east of France, around the same time, Henry of Langenstein, a famous German theologian educated in Paris, expressed a contradictory opinion when he asked the following rhetorical question in a letter addressed to the duke of Bavaria: "Why is it that the universities of France are breaking up, that the sun of wisdom is eclipsed there? Learning withdraws to light another people. Are there not now four universities (Prague, Vienna, Heidelberg and Cologne) shining in concert with rays of glorious truth? $«^{3}$ For various reasons, the dialogue between the University of Paris and the new universities of Central Europe has received very little attention so far: late medieval scholastic theology is still considered a decaying movement, to be overtaken by humanism, reform, and scientific revolution; the fragmentation of tertiary education with the founding of numerous new universities on the speriphery< is still understood to entail little intellectual development of pan-European importance before the advent of printing; and the extreme complexity of distinguishing the innovative from the derivative in late medieval texts deters scholars from an investment of time and energy that might prove fruitless. Nevertheless, a complete study of the Sentences questions produced in Paris and in the new universities helps explain the continuities and the discontinuities in the tradition of the medieval universities and, pushing the frontiers of research, it contributes considerably to changing our perceptions about the late fourteenth and early fifteenth centuries as a decadent period.

The main objective of the THESIS project was a pioneering study of a corpus of over 500 manuscripts, all containing questions on the Sentences composed between the mid-fourteenth and mid-fifteenth centuries. On rare occasions, some of these works had drawn the attention of researchers, but the majority of them had never been studied. The size of the corpus and its philological, codicological, historical and philosophical ramifications make this an innovative project in the field, which gives access to a European cultural patrimony that is still unexplored, often found in libraries that are largely inaccessible to scholars from the West, notably in Romania, Hungary and Bulgaria.

This investigation aimed to offer new information concerning the intellectual atmosphere inside European universities in an attempt to respond to various historical questions:

How do the Sentences questions of this period lead to the formation of a European university identity?

Who are the masters of the time?

What is the importance of a set of questions on the Sentences (the modern PhD thesis) in the development of an individual's intellectual career in the late Middle Ages?

What are the relations and exchanges between the University of Paris and the new universities of Central Europe? 
Which are the works on the Sentences acquired (by purchase and thus at the request of the readers) in the university libraries of this epoch and in this area of Europe?

What are the cultural exchanges between secular clerics, monks (Cistercians) and friars (Dominicans, Augustinians, Franciscans, Carmelites)?

How do the religious orders constitute an important factor in the formation of a network for the transfer of knowledge in the universities?

How can we explain the increasing presence of Cistercian and Augustinian authors (more than $40 \%$ of the production of commentaries from this period seemed to belong to Cistercian authors and 30\% to Augustinians)?

In adopting the model of the University of Paris, how do the new universities of Central Europe innovate and clear the way for a new phase in the history of European universities?

The THESIS project tried to respond to these questions on the basis of a meticulous study of the manuscripts and of the context of their production and their reception.

None of these texts has been critically edited in its entirety, and even the fragments that have been printed are few. For this reason, this part of the history of late scholasticism has never constituted the focus of scientific attention or a field of research.

The vast majority of relevant manuscripts are dispersed in the libraries of Europe, many in Eastern Europe. Many of the libraries of Eastern Europe, for example those of Romania, have no catalogues for their holdings, and until today it has thus been impossible to determine their scholarly potential.

The study of the given material requires a deep knowledge of codicology, palaeography, philology, philosophy and history. The goals in the study of this corpus were numerous. Identifying in this corpus a network for the transmission of knowledge entailed simultaneously opening up a new field of research in medieval studies. An interdisciplinary and multinational team contributed to reconstituting the dialogue that existed in the Middle Ages between Paris and Central Europe, since this reconstruction of the old cultural dialogue revealed the continuities and discontinuities that characterized the transfer of knowledge. The THESIS project analysed the texts from multiple angles: production, circulation, reception and cultural impact, and with multiple readings in order to shed new light on late scholasticism.

As an initial step, the THESIS project's goal was to produce a complete guide to the commentaries composed not only at Paris but also in the new universities of Central Europe, Cologne, Heidelberg, Leipzig, Krakow, Prague and Vienna, during a prolific period, starting around 1350 and going until c. 1450 (the so-called slate scholasticisms). The commentaries of c. 120 authors form the corpus, and they are preserved in over 500 manuscripts. We examined and classified all the material. This work was a preliminary investigation based on a very thorough paleographical and codicological study of the manuscripts themselves.

The THESIS project took into consideration the transmission of these university products, which allowed us to reconstruct their reception and to understand how they affected the European cultural landscape. These texts were copied very frequently indeed, and one and the same text might be copied either for use in an institutional context, in a community outside the university milieu, for example in the houses of the religious orders, or as a tool for personal needs, in which case it was integrated into a private collection and, eventually, in a spublic library (colleges, convents and so on). In terms of the surviving number of manuscript witnesses, the popularity of these writings is so great that their study allowed us to trace the dissemination of intellectual knowledge, particularly through the network of universities of this era. 
These texts have several common elements: the same literary genre, which is an asset for us in understanding the continuities and discontinuities in this type of discourse; the same doctrinal issues, which allow us to discern better any doctrinal particularities in late medieval thought; an abundance of surviving codices, which indicates much about their circulation and reception, and consequently the influence of some of them, for instance, the influence of texts copied at Paris on the products of Vienna; and a decisive impact on the formation and consolidation of academic practice in the new context of the universities of Central Europe.

Following the preliminary stage of transcribing specific texts (selected copies of them) from our corpus, the next logical step was to examine them in order to determine the innovative elements in the surviving texts from the period in terms of both form and doctrine. This was accomplished through a comparative reading of the texts, which revealed their hidden face, once we had studied the implicit and explicit sources of the corpus. We focused on the Prologues of these commentaries, since they constitute mini-treatises containing the essence of a given author's thought.

One of the main achievements of the project was the real discoveries concerning the number of manuscripts of the THESIS corpus. During our search in different libraries from Europe, in catalogues and private collections we considerably increased the number of known manuscripts. We can report here three relevant and impressive cases studies: Mihai Maga found 49 new manuscripts in the case of the Sentences questions of Conrad of Soltau (www. conradusdesoltau.thesis-project.ro); the PI and Christopher Schabel found 80 new manuscripts in the case of Nicholas of Dinkelsbühl; the PI attributed 10 new manuscripts in the case of James of Eltville. We managed to publish the results very quickly in order to provide the scientific community with these new data (see the list of publications under >Output on the website of the project: $w w w$.thesis-project.ro).

In the case of most of the authors of questions on the Sentences composed in the late fourteenth and early fifteenth centuries, whether at Paris or in the new universities founded in Central Europe, we did not even possess an accurate and complete list of the manuscript witnesses. For this reason, this corpus required investigations of a textual, codicological and palaeographical nature that would allow us to determine new attributions in the course of our research, more in line with historical reality.

A large number of manuscripts of the Cistercian James of Eltville's ${ }^{4}$ questions (Sentences lectures in 1369) have come down to us under the name of Henry of Hesse, or Langenstein. How can this be explained? The personal connection between James of Eltville and Henry of Langenstein is at the root of a historical confusion, due to the latter's stay in Abbot James' Eberbach Abbey. ${ }^{5}$ The following series of manuscripts containing James of Eltville's questions were falsely attributed to Langenstein: Erfurt, Univ. (Bibl. Amploniana) CA $2^{\circ}$ 118; Klosterneuburg, Chorherrenstifts 304; Leipzig, Univ. 593; Milano, Bibl. Ambr. A. 106; München, BSB, Clm 11591; München, Univ. 91; Wolfenbuttel, HAB, Helmst 230; Wien, ÖNB 4371; Wertheim, Ev. Kirchenbibl. 608. In his classic repertory, Friedrich Stegmüller cited and attributed all of these codices to Henry of Langenstein. ${ }^{6}$ For this reason, in 1966 Justin 
Lang asserted that Henry of Langenstein was the author of a double reading of the Sentences, namely a Lectura Parisiensis, found in MS Alençon, BM 144, and Wien, ÖNB 4319, and a Lectura Eberbacensis corresponding to the manuscripts that Stegmüller attributed to Langenstein. ${ }^{7}$ Lang also transcribed, in the name of Langenstein, the tabula found in MS München, BSB, Clm 11591. The PI compared this transcription with the tabula conserved in Paris BNF lat. 15896, ff. 208v-211 and confirmed the hypothesis of Damasus Trapp, according to which the questions in the Munich codex, Clm 11591, belong to James of Eltville. ${ }^{8}$ The only manuscripts containing Langenstein's authentic commentary turn out to be Alençon, BM 144 (books I-IV), ${ }^{9}$ and Wien ÖNB 4319 (books II-IV), and it is even possible that this text belongs to Langenstein's Viennese period and that it is not in fact a Lectura Parisiensis. ${ }^{10}$ In a publication from 2014, the PI showed that the whole misunderstanding originates with a medieval librarian's misattribution of a manuscript from the German family of Eltville's Sentences questions to Henry of Langenstein. Since this manuscript became the model for others in the dissemination of the text, all the >German « codices of Eltville's text were attributed to Langenstein. Having analysed and collated all the manuscripts, today we can correct this confusion and demonstrate that there is only one version of Eltville's text. An in-depth examination of the doctrine and an edition of the questions led to the discovery that this text played a crucial role in the transmission of knowledge from the University of Paris to the University of Vienna, since five academic generations of professors in Vienna based their teaching in part on Eltville's model. The third volume of the Studia Sententiarum collection is dedicated to this author and to his legacy in Vienna, as a result of our research during project THESIS. ${ }^{11}$

In addition, another complete manuscript of James of Eltville's text has been brought to light: codex Paris, BNF, lat. 15896 (former holdings of the Bibliothèque de la Sorbonne), even if the manuscript's explicit attributes it to a Carmelite rather than a Cistercian: Jacobo Scoto de Alta Villa Ordinis Fratrum Beate Marie de Carmelo (f 220r.). The questions of James of Eltville's contemporary, John Regis, had been falsely assigned to Jean Gerson (1363-1429), ${ }^{12}$ who in fact left no written questions on the Sentences. Some manuscripts of Henry Totting of Oyta had been attributed to Henry of Langenstein. ${ }^{13}$ Two academic years after the Sentences lectures of Eltville, another important bachelor of theology was active, the Augustinian Denis of Modena, yet his work was printed by Poncet le Preux in 1511 under the name Dionysius Cisterciensis. ${ }^{14}$ Denis of Modena's Sentences questions, which in fact copy many of those of the Cistercian Conrad of Ebrach, contain revealing information about the philosophical and theological methodology employed at Paris during his studies.

Lang, Christologie, 62-64.

8 Trapp, Augustinian Theology, 252.

9 Damerau, Sentenzenkommentar, 23.

10 Shank, Logic, University, and Society, 127-128.

11 See Brinzei and Schabel (eds.), The Cistercian James of Eltville († 1393).

12 Combes, Notes, 381-385.

13 Stegmüller, Repertorium, no. 336, 158-159.

14 Zumkeller, Manuscript der Sentenzenlesung, 73. 
Our project intended to uncover misunderstood or unknown texts and to establish their paternity, following the notion that the history of ideas is sterile without the history of texts. Aside from the rarchaeological investigation that the THESIS project proposed for all the relevant manuscripts, the study of their reception and the information that their texts transmit for the authors was a significant means of discovering their intellectual profile. Among these scholars are some of the most prominent figures of the era: a pope (Peter of Candia), cardinals (Pierre d'Ailly, Egidius de Campis), founders of new universities (Henry of Langenstein, Henry Totting of Oyta), a royal confessor (Nicholas of Dinkelsbühl for Duke Albert V), but in addition to these we learned about other important masters and the roles they played in European intellectual history, once our investigation had revealed their authority on the basis of their texts.

The project was extremely successful, due to some surprising discoveries with a great impact on our field. Some of these have already been published, consisting of 3,000 pages of publications: articles and critical editions. To this we can add circa 5,000 pages of transcriptions of incunabula of Sentences questions from the fourteenth century. These transcriptions were published online on the project website. ${ }^{15}$ The most relevant publications from the project are the following volumes: Iohannes de Basilea OESA, Lectura Super Quattuor Libros Sententiarum, Super Primum Librum, vol. I, Super Primum Librum, vol. II, and Super secundum librum; Godescalcus de Nepomuk OCist, Theology as a Scientific Disposition in the Prologue of the Sentences of Godescal de Nepomuk; Nicholas of Dinkelsbühl and the Sentences at Vienna in the Early XVth Century.

This last volume actually inaugurated the book series Studia Sententiarum with Brepols, a collection that project THESIS launched in 2014, inspired by the topic of the project. In 2015 this first volume was awarded the FIP prize of the University of Babes-Bolyai in Cluj-Napoca (Romania). The volume brings together five studies (by M. Brinzei, W.J. Courtenay, A. Dinca, C. Schabel and U. Zahnd) and some editions of texts stemming from a conference held in Paris on 14 September 2013 at the Institut de Recherche et d'Histoire des Textes on the occasion of the acquisition by project THESIS of the fifteenth-century manuscript TM 536 containing the Lectura Mellicencis of Nicholas of Dinkelsbühl. ${ }^{16}$ The volume provides a pioneering investigation of the Faculty of Theology of the University of Vienna after the new institution produced its first students. Taking Nicholas of Dinkelsbühl as our guide to this nascent academic milieu, the five contributors illuminate the university system at Vienna, describe the evolution of doctrine, identify the network of professors that developed the specific curriculum and trace the reception of the academic writings outside the university. Traditionally the history of medieval universities is based primarily on statutes, cartularies or other documents relating to the organization of the university as an institution. The volume inspects the underside of the iceberg and penetrates the academic context of Vienna by reading and editing the texts issuing from the practice of teaching. The individual contributions shed new light on the main pedagogical protagonists, measure the impact of the transmission of ideas between the Universities of Paris and Vienna and provide access to the community of scholars to whom this material was addressed. 
Besides the initial objectives, we can add several new unexpected achievements: The launching of the book series with Brepols, which will focus on publishing studies on the tradition of questions on the Sentences (all texts from the THESIS corpus). Five volumes are planned for the next two years, all resulting from the THESIS project. So far, two other volumes have already been published and have begun to have an impact on our field: William O. Duba, The Forge of Doctrine. The Academic Year 1330-31 and the Rise of Scotism at the University of Paris (see the review of Jacques Verger in Francia-Recensio, 2, 2018) and, as mentioned, The Cistercian James of Eltville ( +1393$)$ : Author at Paris and Authority at Vien$n a$, edited by Monica Brinzei and Chris Schabel .

We have created a project website where we intend published more material in the future. We plan to develop this website as a database, where transcriptions of manuscripts will be available in open access. At present the website already hosts c. 5,000 pages of Latin transcriptions. For each of the authors from our corpus, the website also contains a separate website linked to his name, where we update the general bibliography and also provide a list of manuscripts and sometimes transcriptions of his questions on the Sentences.

In order to better understand the composition of the texts under investigation, we needed to develop some electronic tools to assist in the analysis of the text, for example, a toolchain for generating schematic representations for the logical flow of questions. This application, designed by Mihai Maga, is the schematic representation toolchain that takes as input a list of elements describing the logical structure of a quaestio (arguments, responses, conclusions, corollaries, etc.). It generates a bi-dimensional chart based on a tree model that facilitates examination of the argumentation, the relations inside the text and also the comparison between different questions and different authors. The toolchain uses LaTeX and generates PDFs. The main advantages are the speed of generating the representation, automation in computing logical relations, easy modifications, and typographic quality. This helps the members of the team to map out the structure of a prologue to show the paths of data and to understand the process of its composition. This is an important step in the process of interpretation of the THESIS corpus. ${ }^{17}$

Project THESIS organized four summer schools entitled Meetings for Reading Medieval Manuscripts (Colibita, Romania 2013; Paris 2014; Paphos, Cyprus 2016; Protaras, Cyprus 2017) and an on-going weekly Skype international seminar in which we corrected transcriptions and critical editions as a team while debating codicological and paleographical aspects of manuscripts from project THESIS. The result of the summer schools is that today five students have chosen as topics for their PhD authors and themes connected to the THESIS corpus.

17 For an example please refer to: conradusdesoltau.thesis-project.ro/CdS-S4S-Prol-structure.pdf. 
Project THESIS succeeded in attracting the interest of some talented young scholars in texts from the corpus. Thus the work of editing new texts made real progress in our knowledge about the intellectual production of the universities from the second half of the fourteenth century and first half of the fifteenth. Texts by these authors have been or will soon be published as articles or volumes as results of project THESIS: Pierre Ceffons (C. Schabel); Andrew of Novocastro (A. Irimescu); Facinus de Ast (A. Baumgarten); Gottschalk of Nepomuk (A. Baumgarten, C. Schabel); Conrad of Ebrach (M. Brinzei, D. Coman, C. Schabel); Conrad of Soltau (M. Maga); James of Eltville (A. Anisie, A. Baneu, A. Baumgarten, M. Brinzei, L. Cioca, D. Coman, I. Curut, A. Marinca, M. Pantea, C. Schabel); John Regis (M. Brinzei, C. Grellard, A. Marinca); Henry of Langenstein (M. Toste); Denis of Modena (M. Brinzei, L. Cioca, C. Schabel); Peter Gracilis (V. Marcolino, J. Slotemaker, J. Witt); John of Wasia (L. Cioca); Pierre d'Ailly (M. Brinzei, C. Schabel, J. Slotemaker) and John Brammart (A. Anisie). 


\section{References}

Brinzei, Monica, Enquête sur la tradition manuscrite du commentaire des Sentences du cistercien Jacques d'Eltville, Bulletin de Philosophie Médiévale 56 (2014) 247-262.

Brinzei, Monica (ed.), Nicholas of Dinkelsbühl and the v at Vienna in the Early XVth Century, Studia Sententiarum 1 (Turnhout, 2015).

Brinzei, Monica and Schabel, Chris (eds.), The Cistercian James of Eltville ( +1393$)$ : Author at Paris and Authority at Vienna, Studia Sententiarum 3 (Turnhout, 2018).

Combes, André, Notes sur les « Sententiae Magistri Johannis Gerson » du manuscrit B.N. lat 15 156, Archives d'Histoire Doctrinale et Littéraire du Moyen Âge 12 (1952) 381-385.

Damerau, Rudolf, Der Sentenzenkommentar des Heinrich von Langenstein (Marburg, 1980).

Duba, William O., The Forge of Doctrine. The Academic Year 1330-31 and the Rise of Scotism at the University of Paris, Studia Sententiarum 2 (Turnhout, 2017).

Gerson, Jean, Oeuvres complètes, ed. Mgr. Palemont Glorieux, vol. VI (Paris, 1964).

Godescalcus de Nepomuk OCist, Theology as a Scientific Disposition in the Prologue of the Sentences of Godescal de Nepomuk, critical edition and study by Alexander Baumgarten (Iasi, 2016) [study in Romanian].

Iohannes de Basilea OESA, Lectura Super Quattuor Libros Sententiarum, Super Primum Librum, vol. I, ed. Venicio Marcolino, coop. Monica Brinzei and Carolin Oser-Grote, Cassiciacum-Supplementband 20/1 (Würzburg, 2016).

Iohannes de Basilea OESA, Lectura Super Quattuor Libros Sententiarum, Super Primum Librum, vol. II, ed. Venicio Marcolino, coop. Monica Brinzei and Carolin Oser-Grote, Cassiciacum-Supplementband 20/2 (Würzburg, 2017).

Iohannes de Basilea OESA, Lectura Super Quattuor Libros Sententiarum, Super secundum librum, ed. Venicio Marcolino, Monica Brinzei, coop. Carolin Oser-Grote, Cassiciacum-Supplementband 21 (Würzburg, 2018).

Lang, P. Justin, Die Christologie bei Heinrich von Langenstein eine Dogmenhistorische Untersuchung (Freiburg, 1966).

Shank, Michael, "Unless You Believe, You Shall Not Understand«: Logic, University, and Society in Late Medieval Vienna (Princeton, 1988).

Stegmüller, Frederich, Repertorium commentariorum in Sententias Petri Lombardi 1 (Würzburg, 1947).

Trapp, Damasus, Augustinian Theology in the Fourteenth Century, Augustiniana 6 (1956) 187-194.

Thorndike, Lynn, University Records and Life in the Middle Ages (New York, 1949).

Verger, Jacques, The Forge of Doctrine. The Academic Year 1330-31 and the Rise of Scotism at the University of Paris by William O. Duba. Reviewed in: Francia-Recensio 2 (2018). Retrieved on 23 October 2018: doi.org/10.11588/frrec.2018.2.48302.

Zumkeller, Adolar, Ein Manuscript der Sentenzenlesung des Augustinertheologen Dionysius von Montina, fälschlich genannt Dionysius Cisterciensis, in: Miscellanea Martin Grabmann. Gedenkblatt zum 10. Todestag (Munich, 1959) 73-87. 